\title{
TEACHING IN ACTION: A MODEL TO UNDERSTAND THE COMPLEXITY OF TEACHERS' DECISIONS IN TEACHING MATHEMATICS
}

\author{
Jörgen Dimenäs ${ }^{1 *}$, Eva Taflin ${ }^{2}$ \\ ${ }^{* 1}$ University of Gothenburg, IDPP, Gothenburg, Sweden, ${ }^{2}$ University College Dalarna, Falun, Sweden; \\ *lemail: jorgen.dimenas@gu.se, ${ }^{2}$ Email: evat@du.se
}

*Corresponding Author: -

Email ID - jorgen.dimenas@gu.se

\begin{abstract}
: -
In this article, we focus on the teaching of mathematics in classrooms. The aim of the present study is to create, describe and test a model for teachers' decisions in action when teaching mathematics. We focused on the classroom as a very complex environment and videotaped three excellent teachers teaching mathematics. An inductive iterative research process was selected to generate theory and conclusions directly rooted in data. The model was tested in different teacher groups, and the categories changed and analyses proceeded. The model relates to Jaworski's (1992), theory the "teaching triad". By using the developed model "teaching in action" it is possible to analyze and describe teaching in mathematics classrooms and find examples of teachers' decisions in action. The model "teaching in action" show the complexity of teachers' work.
\end{abstract}

Keywords: teaching, inquiry, mathematics, teaching triad, model

\section{(ㄷ) (\$) (1)}




\section{INTRODUCTION}

In recent years, a number of different theories of teaching have emerged from the research where "teacher thinking" was one of the first (Clarke \& Yinger, 1977; Clarke, 2004). Subsequently Jaworski's (1994) theory of "teaching triads" and Ball, Thames and Phelp' (2008) Mathematical Knowledge for Teaching (MKT) have been developed. According to Jaworski (2008) the question is how teachers and students create a mathematical environment in the classroom where there are opportunities for students to learn mathematics with understanding and fluency. Teaching should consist of reflective inquiry as it is suggested by Artigue and Blomhøj (2013). Hattie's (2009) research indicates that good teaching is characterized by the teacher having clear intentional educational aims and providing students with opportunities for learning. When the objective of the lesson made visible by having clear and intentional aims, students are provided with more opportunities for learning to occur.

There is a great need to specifically study inquiry-based education where all students' resources can be (allowed to be) made visible. Research on education in Sweden has been influenced by multimodality in teaching as a part of inquiry (Kress \& Van Leeuwen, 2001). Different aspects of teaching and learning should be discussed and valued as the basis for the students' understanding. It requires a teacher who is responsive to what students say and who has the ability to link dialogs with pupils directed to a visualized/multimodal teaching object (Bernstein, 1990). In this study we are interested in teachers teaching mathematics.

The aim of the study is to create a model to describe teachers' decisions in mathematics education.

Shulman's (1987) classic study, "Knowledge and Teaching" emphasized the importance of the "pedagogical content knowledge" (PCK). This study is seen as a starting point in the discussion of teaching versus content. Shulman believed that a teacher's ability to teach is defined by the relationship between pedagogy and content. This means that teachers must have an understanding of subject-specific content in relation to pedagogical questions such as values, curricula and policy documents in different ways and in different contexts. Shulman also emphasized the necessity for the teacher to have knowledge about: their students and their different conditions, different schools' management and material conditions, educational history, philosophy and pedagogy. For teacher students to get this knowledge Shulman (1987) encourages studies in the areas of teaching education, pedagogy, of the school as an institution and of research on teaching and learning in both in and out of school activities. In this article, we especially are focused on the teaching of mathematics in different classroom contexts. Through observation and interviews of teachers we analyze their actions and the underlying decisions they make while teaching ensure that learning is occurring in their classes.

\section{LEARNING AS AN INTEGRAL PART OF TEACHING}

Despite numerous research articles on learning and teaching, we believe that there still is a need to research this topic. There has not been enough research on teacher decision making in mathematics classrooms that explicitly enables teaching. Teaching can be understood as a process related to a content being directed toward the one who learns. At the outset, we would like to further elucidate the concepts of teaching.

Learning is usually about the relationship between student and teacher but it can also be seen in other ways, for example, when a student "explains" to (i.e. teaches) a companion. In research on learning (Marton, 2014), we see that the objectives of the teaching need to be obvious and that these learning objectives can be acquired through education. These learning objectives in the curriculum permeate the Swedish syllabus targets (The Swedish National Agency for education, 2011), and are considered quantitatively measurable in international tests such as PISA (Csapó, B. \&Funke, J, 2017).

Another way to understand learning in relation to study of the classroom is to look at "learning studies" where the starting point is expressed as an object of learning can thus be defined in terms of critical aspects, as a way of seeing something (Marton, 2014). These kinds of studies show learning can be understood as learning objectives or phenomena that are studied are only an expression of how people perceive them, and that different students perceive them more or less successfully thus learning varies from student to student. An aspect of a learning study is when a group of teachers supported by researchers, make various and repeated changes in program so that the critical dimensions are clarified and thus allow the development of knowledge. Because classroom interactions are much more complex this study also will more specifically include the teaching perspective. In this study we see teachers ' and pupils ' interaction as key elements, deliberately avoiding the dichotomizing of learning and teaching emphasized by Clarke (2004).

What do we know and how can we understand research on teaching? Who has the right of interpretation, the researcher or the teacher or in fact none of them? Jaworski (2004) analysis refers various sources which indicates that "exemplary advice" of instruction targeted to teachers, sometimes have very little impact. Jaworski believes that there is a clear rift between the researcher and teacher in the school activities and that there are different ways to understand what is happening in the classroom. The researcher's knowledge about the school is quite different when it gets translated to a school context with a teacher who works with a deeply embedded social environment. A traditional system of school structure, textbooks, tests, attitudes and timetables is something that Jaworski (2004) terms socio systematic factors. One way for these two understandings to meet is to ask how much more powerful it would be if the ideas and theories also came from within the school, i.e. involved teachers? The present study takes Jaworskis (1992) ideas of the "teaching triad" as a theoretical starting perspective. This model provides a lens to examine teaching in mathematics classroom and includes three domains; the management of learning, sensitivity to students and the mathematical challenge. The "teaching triad" can be used not only for making sense of classroom practices, but to also illuminate the different kinds of knowledge teachers need for teaching mathematics. Firstly, there are theories that scientists have posited that can form the basis for studies of how teaching can be developed. Secondly, the teachers' way and understanding the teaching context is bound in school activities, so there is a culture of resistance against theories and suggestions are outside the school. 
Finally, it is rare that theoretical knowledge is embedded in a school context. Jaworski (2004) believes that teachers develop their teaching practice over the time by being explicit with instructions, listening to the students and providing appropriate challenges. In particular this inspired the present study.

Our starting point is to follow teaching and learning in the complex context of mathematic classrooms to investigate skilled teachers engaged in education. Jaworski proposed a teaching design focusing just on the basis of a survey problem where a question is posed that leads to an investigation to gather information that can later be translated into knowledge (Jaworski, 2004).

\section{INQUIRY BASED EDUCATION}

The teaching of mathematics can be related to Dewey's $(1916,1938)$ original educational ideas about basics of teaching which include moments of student's inquiry activities. We further develop this idea and posit that teachers in mathematics instruction sometimes use inquiry as an instrument to generate new knowledge. In the present study and theoretical presuppositions, we highlight teaching as a process that is well-planned with an open educational structure. This is similar to Vygotsky's (1935/1999) idea that considers pupils' "zone of proximal development". This' zone' is where a teacher can teach the content based on how the student experiences a phenomenon and then challenge the student to progress to next development level. Dewey $(1916,1938)$ described reflective inquiry as the basis for both discovery and learning. Hiebert et al. (1996) argued that for Dewey that learning always involves awareness and action and can only be understood from the perspective of the learners' experiences. Artigue \& Blomh øj (2013) suggest that teaching should consist of reflective inquiry as they summarized Dewey's focus on inquiry. They explain that the process of teaching it should consist of reflective inquiry and discovery learning that relates to both everyday life and science. Knowledge is put into practice and starts with learner's experience. The inquiry is developed as a natural part of the pupil being able to be a part of a democratic society. The latter is of importance in education yet it is often not seen as a central aspect of teaching. Gaining and understanding of learning in classrooms can be assisted by conducting a 'learning study' or a 'design' study. Design studies are in-depth studies of learning in connection with the testing of different teaching approaches (Cobb, Confrey, diSessa, Lehrer \& Schauble, 2003). A further method for improving teaching practice which has proved to be of great importance for teachers is to develop the collaborative or a collegial environment professional learning community (Darling-Hammond, 2009; Darling-Hammond et al., 2009). In this model teachers work together to analyze their own practice, which in turn will lead to improve working methods and make teaching more effective. The teachers in the professional learning community are able to test new teaching practices, change and developing teaching with their students, and to than share their experiences with colleagues. To learn together and formulate questions that can be investigated and answered in practical work should make it possible for teachers to collectively recognize and assess curricula. Participating in a professional learning community also improves the teachers' abilities to make professional decisions and conduct research on education related topics.

According to Jaworski (2008) teachers are interested in developing their teaching so that students get a better opportunity to learn in mathematics and to increase their mathematical understandings and skills. The questions she asks is how can teachers and students create a mathematical environment in their classrooms, where there is an opportunity for students to learn Mathematics with understanding and fluency.

\section{INQUIRY AND PROBLEM SOLVING IN MATHEMATICS TEACHING}

The present study is based on a theoretical perspective where inquiry and dialogue are tools in teaching. It is also an expression of the importance of collective learning in a socio-cultural perspective. Different aspects of the teaching and learning aims should be discussed and valued as the basis for the students' understanding. It requires a teacher who is responsive to what students say and has the ability to link dialogue with a visualized teaching objective (Bernstein, 1990). Boaler $(1999,2002)$ comes to a similar conclusion regarding mathematics teaching and believing that students who are textbook-driven perform well on precisely such tasks, but have greater difficulties when the tasks are less structured and more open. Such tasks are managed better by students who are used to working In a group to problem solve, where the context of the problems is central to the process. Research results show that in cases where the students were working on problem solving, they also improve general abilities highlighted in the Swedish curriculum for primary schools (Bergqvist et al., 2009). Research results show that in cases where the students are working on problem solving, they work at the same time with several of the abilities highlighted in the Swedish National Curriculum (The Swedish National Agency for education, 2011). The curriculum states that the skills that students should develop in mathematics is:

-formulate and solve problems using mathematics and also assess selected strategies and methods, -use and analyse mathematical concepts and their interrelationships,

-choose and use appropriate mathematical methods to perform calculations and solve routine tasks, -apply and follow mathematical reasoning, and

-use mathematical forms of expression to discuss, reason and give an account of questions, calculations and conclusion.

The contrast between lessons dominated by work in textbooks in relation to a more complex syllabus raises several questions: What does teaching look like in which all pupils have possibilities to reach school's learning objectives? What does teaching look like when it is based on multimodal information that encourages creative thinking? How is it planned, implemented and evaluated when the lessons have room for flexibility and creativity? Some answers to these questions can be found in research on problem-solving in mathematics education. 
In the Swedish educational context "problem-solving" has been emphasized as central content and a crucial ability to develop (The Swedish National Agency for education, 2011). Further arguments as to why and how students should solve problems, is present in research literature (Kilpatrick, 1985; Lester, 1983; Schoenfeld, 1985; Silver, Leung \& Cai, 1995; The Swedish National Agency for education, 2011). One such argument is that students should learn the problem-solving process, which involves knowing how to treat a problem when you don't know how to fix it immediately. Another argument is that students should become critical reviewers of what can be recognized to able to determine what is right/wrong good or bad. In contemporary research, problem-solving gets a prominent role, and several countries have problem-solving as aims for teaching (Törner et al., 2007). In previous studies it has been found that students who work with problem-solving in mathematics show a greater job satisfaction than they do in traditional mathematic lessons with a main focus on the textbook (Taflin, 2007, 2011).

A special framework for mathematics is Schoenfelds (2012, 2014), who called his framework TRU (Teaching for Robust Understanding - TRU) to characterize learning environments, which is about

"Five Dimension of Powerful Mathematics Classroom". These Dimensions are "The Mathematics", "Cognitive Demand (Room to Grow)", "Equitable Access to Content", "Agency,

Authority and Identity", "Use of Assessment". The framework are intended to support teachers, coachers, and learning communities in planning and reflecting on instruction, with a focus on enhancing instruction along these five dimensions.

\section{A MULTIMODALITIES PERSPECTIVE IN MATHAMTICS TEACHING}

In the present study we take into account that multimodality changed in the 21 st century. We noticed that there has been a shift from a linguistic approach (mostly written text and illustrated with pictures (Björkvall, 2009) to more complex design theories related to the media and digital environments that surrounded individual today (Kress, 2010). With multimodality we mean the possibility for teachers and students to use different mediated tools in classroom work (Säljö, 2005). Selander and Kress (2010) believe that learning is a designed multimodal activity, and highlight that "not only the spoken or written word is of importance, but also activities and interaction by means of documents, glances, gestures, spatial positioning, etc" (Selander \& Kress 2010, p. 55).

This is particularly interesting in a mathematical teaching context. By creating multimodal learning tasks and activities we assume that the more students can be active and participate in such mathematic lessons. Multimodal information contributes to more qualified learning where students develop their own explanations, solve problems with different strategies, argue and present mathematical reasoning, and discuss and compare solutions recognized with various forms of representation. There is also research in the educational sciences which shows that multimodal content affects students' identity and that students experience authenticity and ownership of their learning in a manner not found in traditional school work (Danielsson, 2002; Öhman Gullberg, 2008). Wingstedt (2012) sees multimodality as a developing exponential growth of understanding. Despite long-term reform efforts the socio-economic factors such as parents' income, level of education and occupation, remain extremely influential in terms of students' school success. The Swedish National Agency for Education (2009) reports, after a period of reduced inequality, these differences have begun to increase again. The school's increasing emphasis on reading and writing and, above all, on the individually school work is more or less alien to students depending on their socio-cultural background. A multimodal approach can offer students a more equal starting point. The idea is to expand the teaching by varying modalities/means of expression - often in a collective working process - which can benefit students who are usually do not considered as sucessful in school (Söderman, 2002; Danielsson, 1998, 2004).

\section{THEORY AND METHOD}

Jaworskis (1992) ideas of the "teaching triad" provides us with a lens to understand teaching in mathematics classroom and includes the three domains; the management of learning, sensitivity to students and the mathematical challenge. We started the data collection videotaping and analyzing three practicing teachers' teaching mathematics with their focus on students work on multimodality and mathematical problem solving (Table 1). The whole lessons where videotaped as were the conversations that followed the classes. All students were age 14 in Year 8 and in mixed ability mathematics classes. However the selection of classes observed had students who were considered high achievers with stronger than average results in relation to the national sample. The lessons can be characterized by a high degree of creative activity from both pupils and teachers. The three teachers have a high degree of self-critical approach to their teaching, which we found in subsequent talks when they commented on the recorded video sequences.

Table 1: Videotaped lessons.

\begin{tabular}{|l|l|l|l|}
\hline & Cecilia & Max & Ajna \\
\hline $\begin{array}{l}\text { The } \\
\text { mathematical } \\
\text { problem }\end{array}$ & $\begin{array}{l}\text { Sandwich and } \\
\text { price (fraction, } \\
\text { divisibility) }\end{array}$ & $\begin{array}{l}\text { The pig on a leash } \\
\text { (Geometry, circle, area) }\end{array}$ & $\begin{array}{l}\text { A box (perimeter- } \\
\text { areavolume, restriction area, } \\
\text { formula) }\end{array}$ \\
\hline
\end{tabular}

We have developed the study design based on the work by Glaser \& Strauss (1967) known as Grounded theory. They describe that it is a purpose of constant comparative method of joint coding and analysis is to generate more systematic theory. Hammersley \& Atkinson (1983) argue that "grounded theorizing" means that analysis of data is not the distinct stage of the research. We understand it as an inductive iterative research process which could generate theory and conclusions directly rooted in data. 
The mathematical problems that formed the content of the lessons are described in the figure above (Table 1). A process of transcription, coding and categorization followed that focused on the decisions that emerged in the teachers' actions in the video sequences. This resulted in a model of categories with underlying questions which than was used by 6 preservice teachers planning, implementing and evaluating their lessons.

The model was than modified again and tested by a group of new 24 other pre-service teachers who planned lessons in mathematics and science. The same pre-service teachers used the model and did video analysis of recorded mathematics lessons. The model was again modified and tested by 37 practicing teachers in a teacher training course who analyzed videotaped lessons. The model was developed, and the original video sequences with the raw data were subsequently analyzed and categorized (Table 2).

Table 2: Six stages of research used for confirmation and categorization of the model.

\begin{tabular}{|c|c|c|c|c|c|}
\hline $\begin{array}{l}3 \\
\text { Case, video } \\
\text { recording, call. } \\
\text { Analysis and } \\
\text { categorization }\end{array}$ & $\begin{array}{l}6 \quad \text { Teacher- } \\
\text { student planning } \\
\text { implementatio } n \\
\text { and evaluation } \\
\text { of math lessons. }\end{array}$ & $\begin{array}{l}24 \\
\text { Student teachers plan } \\
\text { their instruction in } \\
\text { mathematics, } \\
\text { engineering, biology, } \\
\text { chemistry, physics }\end{array}$ & $\begin{array}{l}24 \text { Teacher- } \\
\text { student } \\
\text { video } \\
\text { analysis of } \\
\text { recorded } \\
\text { math } \\
\text { lessons. }\end{array}$ & $\begin{array}{l}37 \\
\text { Teachers in } \\
\text { teacher } \\
\text { training } \\
\text { analyzes of } \\
\text { films. }\end{array}$ & $\begin{array}{l}\text { Final } \\
\text { model }\end{array}$ \\
\hline
\end{tabular}

To summarize, the analysis was focused on teachers' actions and their comments in follow-up interviews, and coded into qualitative categories. The categories changed during the research process related to the different sample groups. When all data from the different groups were analyzed a more stable pattern of categories was identified, which resulted in the final model presented.

\section{TEACHING IN ACTION, A MODEL}

After testing the model in six research stages it resulted in seven qualitative categories presented in the figure below (Figure 1). The categorization is example on teachers' decisions and resulted in an inductive developed model called "Teaching in action".

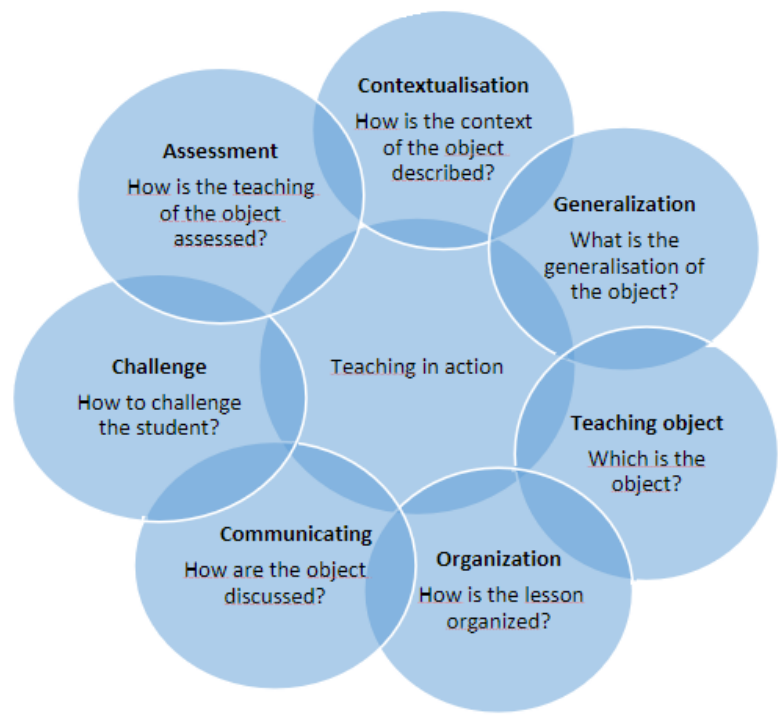

Figure 1: Teaching in action.

\section{RESULT AND ANALYSIS}

We have found that education in mathematics focusing on problem-solving, more or less involves seven key factors that we have categorized, in ongoing action. The seven categories can be used to provide answers to questions about what object is in focus? How is the teaching done? How can the context be described? How to communicate student achievement? How to challenge the student? How is the teaching of the object assessed? The results correspond to some extent with Jaworski's empirical grounded framework "teaching triad"; the management of learning, sensitivity to students and the mathematical challenge (Jaworski, 1992) and to Schoenfelds (2012, 2014) TRU. In relation to our results we find that the three main categories in the "teaching triad" surround the seven categories presented in this study, describing the model "teaching in action". Teaching in action is a specific empirical grounded framework illuminating skilled and competent teachers teaching mathematics and should be seen as a model for professional knowledge applied to action.

The analyze of the empirical data identified seven categories as can be seen below. 
Table 3: Teaching object.

\begin{tabular}{|l|l|l|l|}
\hline Category & Cecilia & Max & Ajna \\
\hline $\begin{array}{l}\text { Teaching } \\
\text { object }\end{array}$ & $\begin{array}{l}\text { fractions and percentages in } \\
\text { different ways, different } \\
\text { representations. }\end{array}$ & $\begin{array}{l}\text { circle, area, } \\
\text { circle-sectors. }\end{array}$ & $\begin{array}{l}\text { area, maximum volume, } \\
\text { connection area-volume, } \\
\text { formula. }\end{array}$ \\
\hline
\end{tabular}

Teaching object means the selection of objects focused in relation to students learning. This can also be some of the skills that students should develop in mathematics.

Table 4: Organization.

\begin{tabular}{|l|l|l|l|}
\hline Category & Cecilia & Max & Ajna \\
\hline Organization & $\begin{array}{l}\text { groups organized } \\
\text { randomly, students } \\
\text { working together, } \\
\text { different solution. }\end{array}$ & $\begin{array}{l}\text { the teacher writes on the } \\
\text { "black board". Today it is } \\
\text { about... Working in groups } \\
\text { with one big paper. }\end{array}$ & $\begin{array}{l}\text { repetition, group activity, } \\
\text { interaction, colored paper } \\
\text { and scissors, different boxes } \\
\text { of the same paper area. }\end{array}$ \\
\hline
\end{tabular}

The category identifies how teacher organizes the classroom and the students for communication with the teacher, with other students' and with different materials.

Table 5: Contextualization.

\begin{tabular}{|l|l|l|l|}
\hline Category & Cecilia & Max & Ajna \\
\hline Contextualization & $\begin{array}{l}\text { money and sandwich: civic competence, } \\
\text { reality can be described by mathematics. }\end{array}$ & $\begin{array}{l}\text { a pig: to learn } \\
\text { about circles. }\end{array}$ & $\begin{array}{l}\text { the box, to } \\
\text { find } \\
\text { formula. }\end{array}$ \\
\hline
\end{tabular}

Mathematics is an abstract subject and as such may not appear to be directly applicable in students' everyday life. This fact requires teachers to be competent in transferring mathematics into appropriate contexts, just as students are required to transfer their everyday knowledge into mathematical expressions.

Table 6: Generalization.

\begin{tabular}{|l|l|l|l|}
\hline Category & Cecilia & Max & Ajna \\
\hline Generalization & $\begin{array}{l}\text { the ability to move between the different } \\
\text { forms of representation, that is, to } \\
\text { discover the relations between the } \\
\text { general and specific. }\end{array}$ & $\begin{array}{l}\text { different } \\
\text { kinds ounting } \\
\text { gives the } \\
\text { same answer. }\end{array}$ & $\begin{array}{l}\text { you calculate } \\
\text { the volume and } \\
\text { what the } \\
\text { formula is? }\end{array}$ \\
\hline
\end{tabular}

All instruction aims, in some sense, to find generic characteristics and general relationships. The circle drawn by students in the problem-solving phase is an example of a generalized image that is independent of the context. The starting point in Ajnas lesson is a square which was later to be used for calculations concerning volumes.

Table 7: Communicating.

\begin{tabular}{|l|l|l|l|}
\hline Category & Cecilia & Max & Ajna \\
\hline Communicating & $\begin{array}{l}\text { students should have } \\
\text { done it for real and it } \\
\text { had brought them } \\
\text { together with younger } \\
\text { children in age 10. }\end{array}$ & $\begin{array}{l}\text { their counting on } \\
\text { a big paper and } \\
\text { explain to each } \\
\text { other. }\end{array}$ & $\begin{array}{l}\text { different forms of expression, } \\
\text { dramatization used as a a } \\
\text { complement to the mathematical } \\
\text { symbol } \\
\text { communicating the dimensions } \\
\text { of the boxes }\end{array}$ \\
\hline
\end{tabular}

The multimodal communication has increased students' opportunities to vary their learning and also makes it possible for teachers to plan and implement more varied teaching. In all cases they encourage different forms of expression that use the back of the pictures and the dramatization as a complement to the mathematical symbol language. 
Table 8: Challenge.

\begin{tabular}{|l|l|l|l|}
\hline Category & Cecilia & Max & Ajna \\
\hline Challenge & $\begin{array}{l}\text { it will be a challenging problem so } \\
\text { that you can actually say that the } \\
\text { answer is wrong immediately, and } \\
\text { then they are forced to continue } \\
\text { and I think they are fun. }\end{array}$ & $\begin{array}{l}\text { this task gives a } \\
\text { challenge to the } \\
\text { students, } \\
\text { because there } \\
\text { are different } \\
\text { solutions }\end{array}$ & $\begin{array}{l}\text { relationship betwen and restriction } \\
\text { volume and a formula requires } \\
\text { area as a calculations } \\
\text { and correct conclusions. }\end{array}$ \\
\hline
\end{tabular}

All three practicing teachers challenge students by using a task in which the accounts of the solution can be done in different ways.

Table 9: Assessment.

\begin{tabular}{|l|l|l|l|}
\hline Category & Cecilia & Max & Ajna \\
\hline Assessment & $\begin{array}{l}\text { the teacher asks } \\
\text { individual question, } \\
\text { gives feedback about } \\
\text { the processes. }\end{array}$ & $\begin{array}{l}\text { a he have worked } \\
\text { selfassessment } \\
\text { matrix". }\end{array}$ & $\begin{array}{l}\text { the teacher walks around and } \\
\text { asks questions and wants the } \\
\text { students to find formulas to } \\
\text { explain the connection. }\end{array}$ \\
\hline
\end{tabular}

Evaluation and assessment of students' learning has gained a greater importance in the context of many students. All three analyzed lessons are marked by an interactive and formative assessment following an instruction process. It has been shown that students need to have both written and oral "feedback" (without numbers and letters) in order to understand what it is to be learnt.

\section{DISCUSSION OF THE MODEL}

Through studies on teacher education, it has been possible to construct models that can support the teachers to plan their teaching. Successful teachers can be identified as having knowledge of their subject and an awareness of the educational factors leading to good teaching (Marton, 2014; Schulman, 1987; Smith \& Stein, 2011). Jaworski (2004) problematizes this by referring to different sources that states that "exemplary advice" developed from research on education aimed at teachers, can have very little impact on teaching. In the present study, we have focused on teachers teaching mathematics by highlighting the actions and decisions that teachers make. This has been done through videotaped mathematics lessons and has resulted in the creation of a model for teachers that we call 'teaching in action'. The lessons in mathematics all had a focus on problem solving with an investigative approach (Dewey, 1916, 1938; Jaworski, 2004). The concept of grounded theory helped us to create the model which was tested by both teachers and pre-service teachers (Glaser $\&$ Strauss, 1967; Hammersley \& Atkinson, 1983). The model highlights the complexity of teaching and has become useful when the concrete application support teachers' planning, implementation and evaluation of lessons in mathematics (Ball, et al, 2008; Jaworski, 2004; Shulman, 1987).

\section{CONCLUSIONS}

Our conclusion is that the model "teaching in action" can be a useful tool for teachers and preservice teachers to obtain a deeper description and understanding of teaching decisions and actions in the classroom. By using the model "teaching in action" it can be possible to analyze and describe teaching in mathematics and find examples of teachers' decisions in action. The model "teaching in action" also shows the complexity of teachers' work. There is a lot of tacit knowledge in teachers' decisions on action and this often leads to new decision -actions.

\section{References}

[1]. Artigue, M \& Blomhøj, M. (2013). Conceptualizing inquiry-based education in mathematics. ZDM Mathematics Education, 45, 797-810.

[2]. Ball, D. L., Thames, M. H., \& Phelps, G. (2008). Content knowledge for teaching: What makes it special? Journal of Teacher Education, 59(5), 389-407.

[3]. Bergqvist, E., Bergqvist, T., Boesen, J., Helenius, O., Lithner, J., Palm, T. \& Palmberg, B. (2009). Matematikutbildningens mål och undervisningens ändamålsenlighet-grundskolan våren 2009, NCM, UFM.

[4]. Bernstein, B.(1990). Class, Codes and Control. Vol. 4, The Structuring of Pedagogic Discourse. London: Routledge.

[5]. Björkvall, A. (2009). Den visuella texten - multimodal analys $i$ praktiken. Stockholm: Hallgren \& Fallgren Studieförlag AB.

[6]. Boaler, J. (1999). Participation, knowledge, and beliefs: A community perspective on mathematics learning. Educational Studies in Mathematics, 40 (3), 259-281.

[7]. Boaler, J. (2002). The development of disciplinary relationships: Knowledge, practice, and identity in mathematics classroom. For the Learning of Mathematics, 22 (1), 42-47.

[8]. Clarke, C. M \& Yinger, R. J. (1977). Research on teacher thinking. Curriculum inquiry, 7 (4), 279394.

[9]. Clarke, D. (2004). Patterns of participation in the mathematichs classroom. Proceedings of the $28^{\text {th }}$ Conference of the International Group for the Psychology of Mathematics Education, Vol 2, 231-238. 
[10]. Cobb, P., Confrey, J., diSessa, A. A., Lehrer, R., \& Schauble, L. (2003). Design experiments in educational research. Educational Researcher, 32(1), 9-13.

[11]. Csapó, B.,\&Funke, J. (2017). The Nature of Problem Solving. OECD Publishing.

[12]. Danielsson H. (1998). Video som språk och kommunikation. Barn och unga skapar med video i skolan. Licentiatuppsats. Pedagogiska institutionen, Stockholms universitet.

[13]. Danielsson H. (2002). Att lära med media. Om det språkliga skapandets villkor i skolan med fokus på video. Doktorsavhandling. Pedagogiska institutionen, Stockholms universitet.

[14]. Danielsson H. (2004). Skolbio Stockholm- Kartläggning och utvecklingsidéer.

[15]. Medioteket/Uppdragsavdelningen, Stockholms stads utbildningsförvaltning.

[16]. Darling-Hammond, L.(2009). Teacher Learning. What Matters? Research Review February 2009, Volym 66, Number 5, pp.46-53.

[17]. Darling-Hammond, L., Chung Wei, R., Andree, A., Richardson, N. \& Orphanos, S. (2009).

[18]. Professional learning in the learning profession. A status Report on Teacher Development in the United States and Abroad. National Staff Development Council and the School Redesign Network at Stanford University.

[19]. Dewey, J. (1916). Democracy and education. New York: Mcmillan.

[20]. Dewey, J. (1938). Logic: The theory of inquiry. New York: Holt.

[21]. Driver, R. (1986) The Pupil as Scientist? Philadelphia: Open University Press.

[22]. Glaser, B. G. \& Strauss, A. L. (1967). The Discovery of Grounded Theory. Startegies for Qualitative Research. New Brunswick: Aldine Transaction.

[23]. Hattie, J. (2009). Visable learning. A synthesis of over 800 meta-analyses relating to achievement.

[24]. London and New York: Routledge, Taylor \& Francis group.

[25]. Hammersley, M. \& Atkinson, P. (1983 ) Ethnography-Principles in practice. Routledge: London.

[26]. Hiebert, J., Carpenter, T.P., Fennema's, E., Fuson, K., Human, P., Murray, H., et al. (1996). Problem solving as a basis for reform in curriculum and instruction: The case of mathematics. Educational researcher, 25(4), 1221.

[27]. Jaworski, B. (1992). Mathematics Teaching: What is It? For the Learning of Mathematics 12.

[28]. FLM Publishing Association, White Rock, BC.

[29]. Jaworski, B. (1994). Investigating mathematics teaching. A Constructuvistic Enquiry. London. The Farmer Press.

[30]. Jaworski, B. (2004). Grappling with complexity: Co-learning in Inquiry Communities in Mathematics Teaching Development. Proceedings of the $28^{\text {th }}$ Congerence of the International Group for the Psychology of Mathematics Education Vol I, 17-36.

[31]. Jaworski, B.(2008). Insiders and outsiders in Mathematics teaching development: The design and study of classroom activity. In Research in Mathematics Education 6:1, pp3-22.

[32]. Kilpatrick, J. (1985). A Retrospective Account of the Past 25 years of Research on Teaching

[33]. Mathematical Problem Solving. In E. A. Silver (Ed.). Teaching and Learning Mathematical Problem Solving: Multiple Research perspectives. London: Lawrence Erlbaum Associates. pp. 1-15.

[34]. Kress, G., \& Van Leeuwen, T. (2001). Multimodal Discourse: The Modes and Media of Contemporary Communication. London: Arnold.

[35]. Kress, G. (2010). Multimodality: A semiotic approach to contemporary communication. Abingdon:

[36]. Routledge.

[37]. Lester, F. K. Jr. (1983). Trends and Issues in Mathematical Problem- Solving Research. In R. Lesh \& M. Landau (Eds.). Acquisition of Mathematics Concepts and Processes. New York: Academic Press, Inc. (pp. 229-261).

[38]. Marton, F. (2014). Necessary Conditions of Learning. New York: Routledge.

[39]. Schoenfeld, A. H. (1985). Mathematical Problem Solving. Orlando: Academic Press.

[40]. Schoenfeld, A. H. (2012). Classroom observations in theory and practice. ZDM, Mathematics Education, Karlsruhe.

[41]. Schoenfeld, A. H. (2014). Thoughts on scale. ZDM, Mathematics Education, Karlsruhe.

[42]. Selander, S. \& Kress, G. (2010). Design för lärande - ett multimodalt perspektiv. Stockholm: Norstedts.

[43]. Shulman, L.S. (1987). Knowledge and Teaching: Foundations of the New Reform. Harvard Educational Review 57 (1), 1 - 21 .

[44]. Silver, E; Leung, S. S. \& Cai, J. (1995). Generating Multiple Solutions for a Problem: A Comparison of the Responses of U.S. and Japanese Students. Educational Studies in Mathematics. Vol. 28. (pp. 35-54).

[45]. Smith, S. M. \& Stein, M. K. (2011). Five Practices for Orchestrating Productive Mathematics Discussions. NCTM.

[46]. Säljö, R. (2005). Lärande och kulturella redskap: Om lärprocesser och det kollektiva minnet.

[47]. Söderman C. (2002). Kan en mediepedagogisk undervisning stärka en elevs kommunikativa förmåga? Utvecklingsarbete - Rapport. Centrum för media och IT i grundskolan, Piteå kommun. Norstedts Akademiska Förlag.

[48]. Taflin, E. (2011). Rika matematiska problem - guldläge för bedömning. I Bartholdsson, A. \& E. Hultin (red.). Praktiknära forskning inom skola och lärande. Arbetsrapport. Högskolan Dalarna, Kultur och lärande, ISSN 1403$6878 ; 2$. s.139-153.

[49]. Taflin, E. (2007). Matematikproblem I skolan - för att skapa tillfälle till lärande. Doktorsavhandling. Institutionen för Matematik och Matematisk statistik. Umeåuniversitet.

[50]. The Swedish National Agency for education, 2009, What affects results in Swedish elementary school.

[51]. The Swedish National Agency for education, 2011, Curriculum mathematics. 
[52]. Törner, G.\& Schoenfeld, A.H. \& Reiss, K.M. (2007). Problem solving around the world: summing up the state of the art. ZDM, Mathematics Education, Karlsruhe.

[53]. Wingstedt, J. (2012). Funktionell analys av musik i film and multimodalt berättande gestaltningar. I G. Ternhag \& J. Wingstedt. (red.) På tal om musikproduktion. Elva bidrag till ett nytt kunskapsområde. Göteborg: Bo Ejeby Förlag,s.160-182.

[54]. Vygotsky, 1. (1935/1999). Problems in the teaching and the intellectual development of school age.

[55]. Included in g. Lafrance (eds.), Vygotsky and the school. Lund: Studentlitteratur.

[56]. Öhman-Gullberg, L. (2008). Laddade bilder. Doktorsavhandling. Institutionen för didaktik och pedagogiskt arbete, Stockholms universitet. 